4. Шульга Т.М., Кононенко Л.В. Податкова амністія в Україні в контексті світового досвіду. URL: https://osau.edu.ua/ (дата звернення 25.09.2021).

DOI https://doi.org/10.30525/978-9934-26-148-0-35

\title{
ЗАБЕЗПЕЧЕННЯ НОРМАТИВНО-ПРАВОВОГО РЕГУЛЮВАННЯ ОБІГУ КРИПТОВАЛЮТ В УКРАЇНІ ЯК ОСНОВА ПРОТИДІЇ ЇХ ПРОТИПРАВНОМУ ВИКОРИСТАННЮ
}

\author{
Мельник Д. С. \\ кандидат юридичних наук, дочент кафедри права \\ ПЗВО «Міжнародний класичний університет імені Пилипа Орлика»
}

\section{Петрова О. С.}

здобувач вищчої освіти 2 курсу спеціальності 081 Право ПЗВО «Міжнародний класичний університет імені Пилипа Орлика» м. Миколаїв, Україна

Світові процеси глобалізації та стрімкий розвиток інформаційних технологій зумовили виникнення нових загроз національній безпеці України у фінансовій, інформаційній та інших сферах.

Зокрема, сучасні світові тенденції свідчать про активне використання криптовалют у протиправній діяльності - легалізації доходів, одержаних злочинним шляхом, фінансування терористичної й сепаратистської діяльності, посягань на конституційний лад та державну владу, протиправного виведення капіталів за кордон, внаслідок чого виникають численні загрози та ризики для національної безпеки багатьох держав світу, у т.ч. й України.

Зокрема, Міністерство юстиції США заявило про викриті факти використання РФ криптовалют для фінансування ведення підривної діяльності на американській території, у т.ч. хакерські атаки на державні установи протягом 2014 - 2018 років та втручання у вибори Президента США у 2016 році. Також у звіті Мін'юсту США про боротьбу 3 торгівлею наркотиками за 2017 рік зазначено про використання операцій з криптовалютами для відмивання коштів, отриманих злочинним шляхом. У грудні 2017 року Федеральною прокуратурою США спільно з Об'єднаним АТЦ ФБР (м. Нью-Йорк) викрито факт використання 
криптовалюти для відмивання злочинних активів, та подальшого фінансування терористичної організації ІДІЛ.

Не $\epsilon$ винятком і Україна, де у лютому 2019 року саме розрахунки у криптовалюті офіційно визнано СБУ одним із головних механізмів фінансування т.зв. «ДНР/ЛНР». Попередньо 01.02.2018 прес-центром СБУ повідомлено про викритий механізм фінансування НЗФ т.зв. «ДНР/ЛНР» та антиукраїнських Інтернет-ресурсів 3 використанням криптовалют [1].

Також протягом 2016-2018 років невстановленими особами здійснювалося блокування сайтів низки державних установ та ураження їх інформаційних ресурсів шкідливим програмним забезпеченням з вимогами винагороди у криптовалюті за їх розблокування.

Згідно з оцінками Інтерполу та Європолу, популярність криптовалют як засобу розрахунків серед злочинців стрімко зростає і вже через кілька років їх можна буде визнати основним платіжним інструментом у злочинному світі.

Наразі лише окремі держави світу (насамперед, Бразилія, Білорусь, Сінгапур, США, Японія) визначилися у правовому статусі криптовалюти та вжили заходів щодо законодавчого врегулювання їх обігу. Однак поняття «криптовалюта» та порядок іiі створення й проведення операцій 3 нею залишаються неврегульованими нормами законодавства більшості країн.

Отже наразі на міжнародному рівні відсутні єдині стандарти регулювання діяльності у сфері створення і обігу криптовалют, їх контролю національними регуляторами. Водночас міжнародними установами вже вжито низку заходів щодо посилення контролю та моніторингу операцій з криптовалютами.

Так Директива ЄC 2015/849 по боротьбі з відмиванням грошей передбачила можливість використання криптовалют з цією метою та визначила повноваження підрозділів Фінансової розвідки (FIU) щодо отримання доступу до інформації про криптовалютні гаманці та біржі [2].

Директива EC 2018/843 (5 AMLD), що набула чинності на початку 2020 року, внесла зміни у Директиви СС 2009/138, 2013/36 і 2015/849 та розширила дію останньої на провайдерів операцій з обміну криптовалют та їх зберігання на електронних гаманцях, надала додаткові повноваження підрозділам Фінансової розвідки з ідентифікації операцій 3 криптовалютами [3].

У свою чергу FATF за дорученням лідерів країн G-20 підготувала та оприлюднила 21.06.2019 оновлену Настанову з ризик-орієнтованого підходу до цифрових активів та постачальників цифрових послуг 3 
рекомендаціями для 36 країн-учасниць щодо протидії відмиванню грошей та фінансуванню тероризму з використанням криптовалют [4]. Рекомендації покликані не допустити використання криптовалют для відмивання грошей, фінансування тероризму та уникнення існуючих заходів контролю і санкцій. Вказані рекомендації вже впроваджуються країнами-учасницями G-20 у національне законодавство.

Не $\epsilon$ винятком і наша держава, законодавчим органом якої 06.12.2019 прийнято нову редакцію Закону України «Про запобігання та протидію легалізації (відмиванню) доходів, одержаних злочинним шляхом, фінансуванню тероризму та фінансуванню розповсюдження зброї масового знищення» [5], де передбачено низку ключових положень щодо моніторингу використання віртуальних (цифрових) активів як засобу розрахунку.

Разом з тим, правовий статус криптовалют, порядок операцій з ними та контролю за їх обігом, функціонування ринку криптовалют попри наявні рекомендації міжнародних установ досі залишаються неврегульованими законодавством України.

Адже віртуальна валюта все ще $є$ складним предметом, який стосується не лише вузької сфери протидії відмивання грошей та фінансування тероризму, але й потребує правового врегулювання низки пов'язаних між собою важливих питань, у т.ч. захисту прав споживачів, пруденційної безпеки, податкового регулювання і питань доброчесності, а також стандартів безпеки мережевих інформаційних технологій тощо [6].

У зв'язку з цим на розгляд ВР України у 2017 році ініціативними групами були внесені три законопроекти щодо унормування обігу криптовалют в Україні: № 7183 від 06.10.2017 «Про обіг криптовалюти в Україні»; № 7183-1 від 10.10.2017 «Про стимулювання ринку криптовалют та їх похідних в Україні» та № 7246 від 30.10.2017 «Про внесення змін до Податкового кодексу України (щодо стимулювання ринку криптовалют та їх похідних в Україні)» [7]. Однак у зв'язку з перезавантаженням у 2019 році системи органів державної влади після виборів Президента та ВР України вказані законопроекти були повернуті ініціаторам.

21.07.2018 Рада фінансової стабільності України затвердила проект концепції визнання криптовалюти як фінансового інструменту, а також регулюванння ринку криптовалют, у т.ч. обов'язків регулятора та його учасників. Концепцію планувалося реалізувати у два етапи до 2021 року: на першому (2018 - 2019 рр.) визначити правовий статус криптовалют, визнати підприємницькою діяльністю надання послуг 3 обміну криптовалют на фіатні валюти; на другому (2020 - 2021 рр.) - визнати 
суб'єктами первинного фінансового моніторингу провайдерів гаманців для зберігання криптовалют, розробити законодавство щодо регулювання обігу криптовалют в Україні [8].

Наразі на доопрацюванні у ВР України перебуває новий законопроект «Про віртуальні активи» від 11.06.2020 № 3637 [9], вже розглянутий у першому читанні. Проектом закону визначено поняття «віртуального активу», наближене до відповідного визначення FATF, принципи державного регулювання обігу віртуальних активів, засади формування цивілізованого ринку таких активів, надання пов'язаних 3 ними послуг та їх адміністрування, а також діяльність постачальників послуг, пов'язаних з їх обігом. Функції центрального органу виконавчої влади, який формує i реалізує державну політику у сфері обігу віртуальних активів, буде покладено на Мінцифри.

Однак запропоноване розробниками визначення «постачальники послуг, пов'язаних з обігом віртуальних активів не узгоджується 3 підходами Директиви Європарламенту та Ради ЄС від 30.05.2018 № 2018/843/СС. У проекті відсутні положення щодо унормування процедур ідентифікації власників віртуальних активів з урахуванням підходів щодо їх деанонімізації, визначених директивою. Законопроектом не враховані положення Рекомендації FATF 15 (у редакції 2020 р.) щодо застосування ризик-орієнтованого підходу до діяльності пов'язаної із віртуальними активами. Тому на думку Головного експертного управління ВР України, проект потребує доопрацювання.

Разом з тим, потребують належної реалізації норми нової редакції Закону України «Про запобігання та протидію легалізації (відмиванню) доходів, одержаних злочинним шляхом, фінансуванню тероризму та фінансуванню розповсюдження зброї масового знищення» від 06.12.2019, які передбачають низку новацій щодо організації моніторингу використання віртуальних активів як засобу розрахунку та протидії відмиванню грошей та фінансуванню тероризму з використанням криптовалют.

Також 3 урахуванням вказаних законодавчих новацій актуальним $є$ впровадження оновлених рекомендацій FATF щодо протидії відмиванню грошей та фінансуванню тероризму 3 використанням криптовалют [10] у практику роботи уповноважених державних органів України. Рекомендації покликані не допустити використання криптовалют для відмивання грошей та уникнення існуючих заходів контролю і санкцій.

При цьому, на переконання експертів, на фоні посилення державного контролю над бізнесом важливо не допустити переміщення процесів 
відмивання грошей, фінансування тероризму та іншої протиправної діяльності 3 використанням криптовалют на нерегульовані децентралізовані майданчики.

\section{Література:}

1. СБУ викрила механізм фінансування тероризму через конвертацію криптовалют. URL: https://ssu.gov.ua/ua/news/1/category/21/view/4344\#. HME5oKQx.dpbs.

2. Директива CC 2015/849 по боротьбі з відмиванням грошей. URL: https://bloomchain.ru/legal/evropejskij-soyuz-prinyal-novuyu-direktivu-poborbe-s-kriptovalyutnymi-prestupleniyami/.

3. Директива EC 2018/843 (5 AMLD). URL: https://eur-lex.europa.eu/ legal-content/EN/TXT/?uri=CELEX\%3A32018L0843\#.

4. Настанова FATF 3 ризик-орієнтованого підходу до цифрових активів та простачальників цифрових послуг» від 21.06.2019. URL: http://www.fatf-gafi.org/publications/fatfrecommendations/ documents/ public-statement-virtual-assets.html.

5. Закон України «Про запобігання та протидію легалізації (відмиванню) доходів, одержаних злочинним шляхом, фінансуванню тероризму та фінансуванню розповсюдження зброї масового знищення». URL: https://zakon.rada.gov.ua/laws/show/361-20.

6. Виртуальные валюты: руководство по применению рискориентированного подхода. URL: http://www.eurasiangroup.org/ files/FATF_docs/ROP_Virtualnye_valyuty.pdf (дата обращения: 01.02.2017).

7. Криптовалюты в Украине: судебная практика и новые законопроэкты. URL: https://sud.ua/ru/news/publication/109991kriptovalyuty-v-ukraine-sudebnaya-praktika-i-novye-zakonoproekty.

8. Мінекономрозвитку ініціює легалізацію криптовалют в Україні. URL: http://www.me.gov.ua/News/Detail?lang=uk-UA\&id=2cc04fa0-3577$49 \mathrm{c} 7-\mathrm{a} 465-\mathrm{bd0f} 3 \mathrm{f} 61 \mathrm{bed} \&$ title $=$ MinekonomrozvitkuInitsiiuLegalizatsiiuKriptovaliutVUkRAIn.

9. Проект Закону України «Про віртуальні активи» від 11.06.2020 № 3637. URL: https://w1.c1.rada.gov.ua/pls/zweb2/webproc4_1?pf3511= 69110.

10. Настанова FATF з ризик-орієнтованого підходу до цифрових активів та простачальників цифрових послуг» від 21.06.2019 URL: http://www.fatf-gafi.org/publications/fatfrecommendations/ documents/ public-statement-virtual-assets.html. 